\title{
LEGAL SCHOLACTIVISTS IN THE THIRD WORLD: BETWEEN AMBITION, ALTRUISM AND ACCESS
}

\section{Cynthia Farid*}

This article argues that legal agents from the Third World play an important role in facilitating and advancing subaltern claims by operating as "scholactivists". The mediums they use for such advances necessarily require leveraging of the international legal discourse and various international forums. However, their success is constrained by the dynamics of the international legal field and the ability to assimilate within a global cosmopolitan class. Legal scholactivists are examined here from a place-based perspective, locating their praxis in the geographical Third World. In so doing, this article traces the life and work of Dr. Kamal Hossain, a celebrated Bangladeshi lawyer with many accolades at home and abroad. In his long and illustrious career, Hossain has voiced subaltern and Third World concerns on the global stage through a variety of mediums including domestic and international legal practice, advocacy, international organizations and various non-profit, non-governmental and civil society organizational efforts. Although the references to Bangladesh may be very specific and are used as an illustration, it is hoped that the claims made in this paper will be generalizable and applicable to similarly situated countries.

Dans cet article, l'auteure soutient que les acteurs juridiques du tiers monde contribuent largement à faciliter et à défendre les revendications subalternes en agissant en universitaires militants. Les moyens dont ceux-ci usent pour faire avancer ces causes exigent forcément l'utilisation du discours juridique international et de diverses tribunes internationales. Par contre, leur succès est limité par la dynamique du champ juridique international et la capacité d'assimiler au sein d'une classe cosmopolite mondiale. Les universitaires militants du droit sont étudiés ici sous l'angle géographique: le lieu d'exercice de leurs activités se situe physiquement dans le tiers monde. Ainsi, l'auteure de l'article donne l'exemple d'un avocat du Bangladesh comme un cas d'école pour faire comprendre en quoi consiste exactement la défense des revendications subalternes. Il est question de la vie et de l'œuvre de Kamal Hossain, avocat bangladais réputé qui a fait une brillante carrière à l'échelle nationale et internationale. Durant sa longue carrière, il a donné expression aux préoccupations subalternes et à celles du tiers monde à

Cynthia Farid is a doctoral candidate at the University of Wisconsin Law School. I have to foremost thank Dr. Kamal Hossain for his time, openness and generosity during our interview. I am also grateful to his colleagues at Kamal Hossain \& Associates, including Barrister Sara Hossain (Partner and a scholactivist in her own right), Barrister Moin Ghani (Associate) and Mr. Shah Jahan (P.A. to Kamal Hossain) for facilitating access to information and insights. I appreciate and thank the editors of this issue for their patience, encouragement and feedback throughout the process of submission and edits. I owe debts of gratitude to Professors Mitra Sharafi, Aziz Rana and Frank Munger for reading and commenting on earlier drafts. I am equally grateful to Dr. Shahdeen Malik, Golnoosh Hakimdavar, Shanthi Senthe and Prabhakar Singh for their invaluable insights. 
l'échelle planétaire par divers moyens, notamment par l'exercice du droit, dans son pays et à l'échelle internationale, en militant pour des causes, en faisant partie d'organisations internationales et en participant aux efforts d'organisation de divers organismes à but non lucratif ou non gouvernementaux et de la société civile. Bien que les références au Bangladesh soient très précises et servent d'exemple, on espère que les affirmations formulées dans cet article seront généralisables et applicables à des pays de la même zone géographique.

\section{BACKGROUND}

This article stems from reflections on discussions in a panel titled "Can the subaltern speak to/at TWAIL?" and other interactions at the Third World Approaches to International law [TWAIL] Conference held on February 21-24, 2015 in Cairo. The Cairo conference reflected on the role of the intellectual, theory and praxis. In line with this theme, this article explores the role of legal agents in and from the Third World. It argues that certain legal agents from the Third World play an important role in facilitating and advancing subaltern claims by operating as "scholactivists". The mediums they use for such advances necessarily require a turn towards internationalization and leveraging the law in various national and international forums. The success of these agents is constrained by the dynamics of the international legal field and the ability to assimilate within a global cosmopolitan class. ${ }^{2}$ Legal scholactivists are examined here from a place-based perspective, locating their praxis in the geographical Third World. ${ }^{3}$ In so doing, this article traces the life and work of Dr. Kamal Hossain, a celebrated Bangladeshi lawyer with many accolades at home and abroad. In his long and illustrious career, Hossain has voiced subaltern and Third World concerns on the global stage through a variety of mediums including domestic and international legal practice, advocacy, international organizations and various non-profit, non-governmental and civil society organizational efforts.

For the purpose of this article, legal agents include actors with legal skill-sets practicing law, working in institutional capacities or otherwise making use of and leveraging the law. For instance, lawyers acting as legal advisors, litigators, experts, scholars and so on would qualify as such agents. Not all such

1 The term "Third World" is to be used interchangeably with the South, the Global South, the non-Western World, the Undeveloped World, referring to the categorization of the world based on economic inequalities tied with histories of colonialism with some coincidental cartographic coherence. Its continuing use in TWAIL and other literature on globalization or postcolonial theory emphasizes the relationship of the Global North and South in light of global processes rather than rigid geography. It is acknowledged that pockets of the Global South can also be found in the geographical North. However, the article is concerned with the geographical Third World. It uses this term in the sense it first appeared as tiers monde to categorize underdeveloped nations. The reason for insisting on such continuous and, perhaps, essentialized usage of the term is to preserve the politics and relevance of place in conversations of the geographical Third World. This will help situate and understand legal agency against geographical complexities. For a consideration of the construction of First, Second and Third Worlds in social sciences, see Carl E Pletsch, "The Three Worlds, or the Division of Social Scientific Labor, circa 1950-1975" (1981) 23:4 Comparative Studies in Society and History 565.

2 See BS Chimni, "Prolegomena to a Class Approach to International Law" (2010) 21:1 Eur J Intl L 57.

3 See Roxann Prazniak \& Arif Dirlik, Places and Politics in an Age of Globalization (Rowman \& Littlefield Publishers: 2001). 
legal agents are concerned with subaltern issues or claims of social justice. Many scholars or academics simply teach and do not write, lawyers approach domestic and international legal practice in a narrow legalistic fashion, and expert consultants blindly follow best practices. This article is concerned with a specific subset of legal agents located in the Third World who engage in social justice concerns. The term scholactivist, commonly associated with pedagogical discourse, captures some of the complexities of these legal agents. ${ }^{4}$ The remaining sections will use the terms legal scholactivist, lawyer and legal agent interchangeably.

Hossain's biography squarely places him as a successful career practitioner as well as a legal scholactivist both at home and abroad. Admittedly, his intellect and qualifications explain his success and demonstrate the role legal agency can play in advancing subaltern causes. However, in addition to altruistic motives, the ability to claim a voice for the subaltern is also based on elite positioning. Legal scholactivists, like Hossain, play a critical role on the ground, working on emancipatory projects that advance socio-economic rights and campaigning against rights violations by asserting those claims in national judicial forums. They also navigate the global and local through mediums such as international courts and arbitration forums in areas as diverse as international trade law, security, natural resources, and so on. Legal scholactivists are advantageously situated between social movements, legal practice and academic circles. This form of agency may require assuming strategic positions inside and outside institutions and within and without the state. It may also involve acquiescing and working with and through power.

Admittedly, scholactivists are one of several actors, including activists, civil society and non-elite groups who may be carriers of law and agents of social change. This article limits its focus to legal agents. Its primary goal is to understand, not the constitutive process of law-which has been discussed at great length by a number of scholars who are referred to in this paper-but the ways in which scholactivists from the Third World acquire for themselves a seat at the table of power to get their voices heard. This article will engage with sociolegal constructions of legal scholactivists, whereby they are implicated in both top-down as well as bottom-up processes of structural and legal change. By testing these claims against the case study of Hossain, this article investigates various aspects of legal agency. First, it examines the various pathways to internationalization. A generational shift among international lawyers like Hossain means the impact of history and globalization has had an attendant effect on internationalization as a gateway to opportunities, whether for professional development or altruistic causes. Moreover, decontextualized internationalization can be unconducive for cultivating social reflexivity among lawyers in the Third World. Second, this article sheds light on the ways in which such lawyers manage the contradictory pressures of the field and negotiate the demands of career and cause. Finally, this article explores the extent to which local conditions and the positionality of Third World scholactivists within the international legal field can facilitate or constrain their success.

4 See Saturnino Borras Jr, "Land Politics, Agrarian movements and Scholar-Activism" (Inaugural Lecture delivered at the International Institute of Social Studies, 14 April 2016) online: <https://www.tni.org/files/publicationdownloads/borras_inaugural_lecture_14_april_2016_final_formatted_pdf_for_printing.pdf $>$; Stephen Petrina, "The New Critiquette and Old Scholactivism: A Petit Critique of Academic Manners, Managers, Matters, and Freedom" (2012) 20 Workplace: A Journal for Academic Labor. 
The remainder of this article is divided into the following parts. Part II presents a framework for the case study in light of sociolegal understandings of legal agency. Part III provides a biographical account of Hossain; Part IV considers the efficacy of scholactivism and the challenges of the legal field in making subaltern claims. The article concludes with thoughts on agendas for collaboration and future research.

\section{THE RELEVANCE AND ROLE OF AGENCY IN FACILITATING SUBALTERN CLAIMS}

Reflections on the panel which inspired this paper, i.e., TWAIL's relationship with the subaltern, emphasized a central role for legal agency. The term subaltern is broad, often controversial and denotes a range of social locations. Put simply, it refers to underclasses who are and have been historically marginalized or excluded from social and political participation and have been or remain under the domination and hegemonic influences of the ruling classes or power structures. ${ }^{5}$ As a result, their voices and histories have been left out of the writing of history all together. As Spivak notes, subaltern voices are subjected to and silenced by the epistemic violence of discourse and power structures. ${ }^{6}$ These voices cannot be recovered through exogenous interrogation. Any such effort leads to the homogenization of subaltern identity and reinforces their subordinate status by retaining the privilege of speaking for the subaltern among the discoursing agents. ${ }^{7}$ This, of course, poses its own problems of representation and distortion. Ultimately, however, the subaltern enters official and intellectual discourse, albeit rarely, through the medium of agents with access to institutional locations of power. This article does not set out to uncover an authentic voice for the subaltern. If subaltern voices cannot be heard through our existing conceptual apparatus, it ultimately becomes our responsibility as scholars to create a new language or medium through which to mediate this deficit. ${ }^{8}$ Beyond the search for a singular definition of TWAIL, it is perhaps easily agreeable that at a basic level TWAIL is concerned with the absence of Third World voices within the international legal discourse. ${ }^{9}$ Thus, TWAIL is also concerned with the subaltern project of excavating marginalized or unheard voices from the periphery.

5 There are variations on the meaning of subaltern. In the Gramscian sense, subaltern generally relates to the proletariat. However, its later usage has varied among subaltern historians and postcolonial theorists. Some common themes include peasants and peasant insurgencies, women and sati practice in colonial India and other subjugated colonial and postcolonial subjects. The meaning of subaltern can also extend to nations. See Gyan Prakash "Subaltern Studies as Postcolonial Criticism" (1994) 99:5 The American Historical Review 1475 at 1476; El Habib Louai, "Retracing the concept of the subaltern from Gramsci to Spivak: Historical developments and new applications" (2012) 4:1 African Journal of History and Culture 4.

$6 \quad$ See Gayatri Chakravorty Spivak, "Can the subaltern speak?” in Cary Nelson and Lawrence Grosberg, Eds, Marxism and the Interpretation of Culture (London UK: Macmillan, 1988) 271 [Spivak, "Subaltern”].

7 Ibid.

8 See Ashis Nandy, Time Warps: Silent and Evasive Pasts in Indian Politics and Religion (New Brunswick, NJ: Rutgers University Press, 2002) at 60.

9 For a representative sample, see Makau W Mutua, "What is TWAIL?" in American Society of International Law, eds, Proceedings of the $94^{\text {th }}$ Annual Meeting, (2000) 31, online: SSRN <https://papers.ssrn.com/sol3/papers.cfm?abstract$\mathrm{id}=1533471>$; Anthony Anghie et al., eds, The Third World and International Order: Law, Politics, and Globalization (Leiden: Martinus Nijhoff, 2003); Bhupinder S Chimni, "Third World Approaches to International Law: a Manifesto" (2006) 8 Intl Community L Rev 3; Obiora Chinedu Okafor, "Critical Third World Approaches to International Law 
Rajagopal challenges the state-centric and top-down approach in the international legal discourse by examining its relationship with social movements (and by extension subaltern claims). A social movements analysis helps reverse the bias of the global over the local in international law by decentering geography. ${ }^{10}$ He suggests an important role for lawyers in connecting social movements and international law, causing the former to affect the latter from below. ${ }^{11}$ Highlighting a symbiotic relationship between mass action and movement intellectuals in the Third World, Rajagopal ascribes to these intellectuals a mediating role between social movements and the global cosmopolitan class. ${ }^{12}$ Legal agents may be associated with social movements in a composite sense as part of this group of intellectuals. However, voicing subaltern claims requires access to power and resources. Elite status is often a pre-requisite to such access. The transnational space inhabited by legal agents is not neutral. It consists of national narratives of elite contestation as well as international relations. Internationalization is integral to the acquisition of status, which is often defined by institutional affiliations or clientele in the Global North. ${ }^{13}$ Law and Society scholars provide useful insights for understanding this process.

\section{A. Sociolegal Constructions of Legal Agency}

Dezalay and Garth, in their multi-volume scholarship on legal elites, examine agency through elite lawyer biographies as entry points to their research on Latin American and Asian countries. ${ }^{14}$ They situate the role of legal elites in constructing the law against the backdrop of colonial legacies, accumulation of various forms of social, economic and legal capital and the contestation over the field of state power. Emphasizing the importance of history, Dezalay and Garth argue that investments in law often determine its symbolic power. Countries like India and the Philippines had far deeper investments in law during colonial rule than Malaysia, Singapore or Hong Kong. As a result, lawyers there function with greater independence and are often at the center of politics when challenging state authority. By this cyclical account, lawyers accumulate social capital during colonial rule, subsequently benefit from it in the independence era, and sustain accumulation by contesting with other political actors. They also trace this cycle through globalization histories of the Cold War, the rise of United States [US] hegemony, and the Washington Consensus.

Adopting a Bourdieusian analytical frame, Dezalay and Garth's account considers the legal order as a set of established institutions and the legal field as a social space or structure for positions of legal agents. ${ }^{15}$ Through a mutually-constitutive relationship, legal agents shape these institutions through

(TWAIL): Theory, Methodology, or Both?” (2008) 10:4 Intl Community L Rev 371; James Thuo Gathii, “TWAIL: A Brief History of its Origins, its Decentralized Network, and a Tentative Bibliography" (2011) 3 Trade L \& Dev 26.

10

11

Ibid

12 Ibid

13 See Yves Dezalay \& Bryant G Garth, Dealing in Virtue: International Commercial Arbitration and the Construction of a Transnational Legal Order (Chicago: University of Chicago Press, 1998) [Dezalay \& Garth, Dealing in Virtue].

14 See Yves Dezalay \& Bryant G Garth, The Internationalization of Palace Wars: Lawyers, Economists, and the Contest to
Transform Latin American States (Chicago: University of Chicago Press, 2002); Yves Dezalay \& Bryant G Garth, Asian Legal Revivals: Lawyers in the Shadow of Empire (Chicago: University of Chicago Press, 2010).

15

Ibid. 
competition, collaboration and conflict. The actions of agents are driven by interest as well as habitus, ${ }^{16}$ which is linked with the acquisition of symbolic capital. ${ }^{17}$ The legal field, through its structure, establishes a system of injunctions and rules of the game which practitioners must engage with, adapt to and over time affect with the accumulation of capital. ${ }^{18}$ This necessitates a certain degree of institutionalization of monopoly over the field. Despite commonly held assumptions about equality and collegiality among members of the bar or academic colleagues, it also establishes an implicit hierarchical system within the field defined by differential professional prestige and power.

Lawyers are integral to the construction of the legal field through serving and legitimating power holders. Law is embedded within competing fields of state power and lawyers broker between its different institutions. In this competition in and around the state for acquiring prestige, legitimacy and credibility, lawyers enjoy different resources. Some are civil servants, while others are more marginal vis-à-vis the state. Their position alters with the successful accumulation and leveraging of capital in addition to political opportunities. In this sense, lawyers act as "double agents" who not only maintain the legitimacy of their clients but also stand for the independent authority of law. While lawyers regularly advance and use their capital for advancing political liberalism, which can empower clients who previously had little or no position in the field of state power, they also engage in self-preservation where the law ultimately serves the field, i.e., interests of the practitioners, by advancing its own legitimacy. Therefore, professional and symbolic gain are major incentives for lawyers and the institutional autonomy of law is a requirement to confront those in political power.

There are parallel national stories of elite competition in states of the Global North and the Global South that legitimate each other. For example, elite competition, or what Dezalay and Garth call "palace wars", influenced law-making or selection of particular modes of governance in many countries of the Global South. These would be legitimated by actors like economists or lawyers within international institutions in the North, while in the other end of this chain, foreign-trained lawyers from the South make selections based on their legal training or make choices based on networks or co-optation. Another example of lawyers acting as power brokers may be found in the history of the formation of leading centres of international commercial arbitration that are engaged in the production of credibility. Competitors are credentialed in ways that would provide potential clients reasons to choose a particular arbitrator or forum. This legitimation exercise can be found in a number of other institutions and, as Hossain's biography will demonstrate, pervade the North-South divide.

16 Habitus consists of dispositions, habitual ways of understanding and inclinations, and the position or condition of existence of the agents within the field. These generate perceptions and practices in the field. For example, the legal field as a symbolic order is associated with the creation and application of law. Through their specific skills and training, legal agents assign social meaning to law, dictating how the field and its activities are understood and designating acceptable norms of behaviour within it. See Pierre Bourdieu, Distinction: A Social Critique of the Judgement of Taste (Cambridge: Harvard University Press, 1984) at 169.

17 Symbolic capital is wealth measured in symbolic as opposed to only economic terms. It includes cultural and social capital consisting of "authority, knowledge, prestige, reputation, academic degrees, and debts of gratitude owed by those to whom we have given gifts or favors" as well as access to networks that may translate into traditional forms of economic capital. The value of these species of capital changes over time with education, age, experience, etc. See Pierre Bourdieu, "Force of Law: Toward a Sociology of the Juridical Field" (1986) 38 Hastings LJ 805 at 812.

18 Terdiman explains Bourdieu's "juridical field" metaphorically as a magnet. A social field exerts a pull upon those who operate within its range and influences patterns of behavior. Ibid at 821. 
Dezalay and Garth's model of elite lawyers emphasizes a top down approach in the construction of law. Several scholars have weighed in on this model. ${ }^{19}$ For instance, a case study of India points towards its rich and diverse civil society, which is made up of many actors including legal elites and non-elites, with internal diversity among them. ${ }^{20}$ Munger cites Thailand as an example where the role of lawyers is complicated by the bureaucratic state. ${ }^{21}$ Lawyers continue to contribute to changes but they are not necessarily working towards creating a place for the profession in the field of state power. Instead, social justice lawyers are frequently connected to transnational networks. Rodríguez-Garavito and Santos add a missing variable, i.e., social movements, to Dezalay and Garth's top-down mapping of the constitutive process of law. ${ }^{22}$ External support and elite connections may impact the outcome of resistance efforts but they do not have deterministic control over social movements. Commitments or strategies of movement beneficiaries and values and ideologies with which they frame their causes may outlive a particular contentious moment, thereby having long-term consequences. An elite-focused approach also ignores the contributions of non-elites, homogenizes the diversity among elites, and collapses disparate movement agendas into one generic category.

Rodríguez-Garavito and Santos advance an alternative concept of subaltern cosmopolitan legality [SCL] which connects law and politics working towards what they call new legal hegemony. ${ }^{23}$ They envisage lawyers and social movements to be reconstituting legal institutions from the lived experiences of marginalized, oppressed and impoverished groups. This is done through sustained political mobilization, collaboration and collective organization. Law and rights are politicized before they are moved into the legal arena. Social movements can take on transnational character and very often lawyers are at the forefront of transnationalizing them. This occurs within an overlapping and plural legal landscape of local, national and international law and among networks connecting the various layers. Lawyers and other movement intellectuals frame their demands and capitalize on the opportunities offered by this plural legal landscape. They use norms and institutions and deploy strategic political and legal tools at every scale. ${ }^{24}$ Therefore, both the state and international institutions serve as terrains for emancipatory struggles and democratic participation. ${ }^{25}$

19 Non-elite agents and other networks of influence can also affect power holders quite independent of powerful elites. See Thomas Risse, Stephen C Ropp, \& Kathryn Sikkink, eds, Power of Human Rights: International Norms and Domestic Change (Cambridge: Cambridge University Press, 1999); Sally Engle Merry, Human Rights and Gender Violence: Translating International Law into Local Justice (Chicago, IL: University of Chicago Press, 2006).

20 See American Bar Foundation, "Researching Law: An Update" online (spring 2010) 21:2 American Bar Foundation 6 $<$ http://www.americanbarfoundation.org/uploads/cms/documents/abf_rl_spring_2010.pdf $>$. In addition, Brahmins have historically dominated the legal profession but, in places like Bombay, members of the Parsi community thrived in the legal profession. See Mitra Sharafi, Law and Identity in Colonial South Asia: Parsi Legal Culture, 1772-1947 (Cambridge: Cambridge University Press, 2014).

21 See Frank Munger, "Globalization through the Lens of Palace Wars: What Elite Lawyers' Careers Can and Cannot Tell Us about Globalization of Law" 37:2 (2012) Law \& Soc Inquiry 476-499.

22 See César A Rodríguez-Garavito \& Boaventura de Sousa Santos, Law and Globalization from Below: Towards a Cosmopolitan Legality (Cambridge, UK: Cambridge University Press, 2005).

23 Ibid. at 12-14.

24 Environmental movements in India involving the Narmada River dam have leveraged tensions between national laws and international laws through a combination of local, national, and regional legal strategies. See Balakrishnan 
While Dezalay and Garth make a strong case that elites are directly involved in the construction of law, Rodríguez-Garavito and Santos, and other sociolegal scholars offer alternatives that can potentially democratize and reconstitute these structures through transnational networks and social movements. SCL helps us understand the bottom up constitutive process of law across the scales of the local and the global. The following section will combine these competing approaches in an effort to understand legal scholactivism. It will also argue that legal agents may not be fully understood in the same deterritorialized way as the construction of law. Significant differences remain when legal agents are situated within a disparate field that is academically divided by geography. This division still subordinates contextual knowledge over universal laws and best practices, and local expertise over the international. Position and geographical location affect legal agency in the Third World. Hence, the notions of place and space are both relevant.

\section{B. Scholactivism and the Politics of Location}

Scholactivism refers to scholar-activism. It includes academic work or committed activist work that is informed by rigorous academic research and is explicitly connected to political projects or movements. There are broadly three types of scholar-activists which include: those primarily located in academic institutions who do activist work and are connected to political projects or movements; those who are principally based in social movements or a political project and engage in scholar-activism from within; and those who are located in non-academic independent research institutions who do activist work and connect with a political project or movements. ${ }^{26}$ Although this term is not commonly associated with lawyers, this article extends it to encompass legal practice, academia and various forms of advocacy and activism. Legal scholactivists navigate dynamics of the legal field while operating across multiple forums, connecting the local and the global. In so doing, they play a distinctively semiotic role in the shaping of both domestic and international law to further claims from, by, and in the Third World.

Legal scholactivists are to be distinguished from the deterritorialized Third Worldist international lawyer and the geographically-bound and politically-charged cause lawyer who may sometimes but not always (and indeed may never) engage with international law. The former is a typology, discussed in recent TWAIL scholarship, defined as "anyone in the contemporary academic disciplines of international law who has made the intellectual/political and professional choices to engage systematically with foundational questions about the nature and causes of heteronomy in the world and about the possibilities for resistance". ${ }^{27}$ In contrast, the latter describes lawyers committed to using law for social or political change and to serving a particular cause by necessarily taking sides in political,

Rajagopal, "Limits of law in counter-hegemonic globalization: the Indian Supreme Court and the Narmada Valley Struggle" in Rodríguez-Garavito and Santos, supra note 22.

25 Rajagopal, supra note 10; Rodríguez-Garavito and Santos, supra note 22.

26 See Borras and Petrina, supra note 4.

27 See Hani Sayed, “On the Political Limits of Pragmatism: Third Worldist International Lawyers and International Institutions”, (2016) online: SSRN <http://ssrn.com/abstract=2785465>. 
social, economic, cultural, legal and moral struggles. ${ }^{28}$ For the scholactivist, these categories will overlap.

Legal scholactivists connect scholarship, policy and praxis, which occupy an unconventional relationship in many countries of the Global South. They operate in multiple capacities; for instance, they participate in social movements, institute legal claims in the course of their work in domestic as well as international forums, advocate for legal reform, and contribute to academia as scholars. Accordingly, the term scholar, lawyer, expert or consultant is fluid. As these individuals theorize about a right handed down by the Constitution or under international human rights laws, a social movement to secure that right is often simultaneously taking place. For example, lawyers may practice in national or international forums but also teach law. They may be active in international advocacy forums, voicing concerns about global inequalities that affect the particular cause they support, and at the same time may be involved in donor-funded non-governmental organization [NGO] initiatives or carry out consultancy assignments commissioned by international organizations with a view to having some agency in shaping local institutions. The role of a scholactivist is characterized by diversification. This is not to suggest or portray legal scholactivists as heroes of all seasons. These actors depend on internationalized credentials and affiliations to advance their careers as well as causes. Legal scholactivists navigate international and local politics in ways that also enhance their own status, while securing positive outcomes. The scholactivist's role requires a plurality of praxis, as well as both national and international forums to channel subaltern demands. For scholactivists, both ambition and altruism coalesce as a common objective. In other words, scholactivists are ideal agents for the SCL project but they are also strategic in ways that speak to Dezalay and Garth.

In order to project her claims from the Third World, the legal scholactivist must speak in universal terms. Access requires acquiring credentials and mastering intellectual tools. Therefore, legal scholactivists must imbibe the language and culture of the disciplinary knowledge of international law or internationally-recognized legal discourse. ${ }^{29}$ This process places a premium on internationalization, which has both benefits and costs associated with it (as discussed in Part IV). It also necessitates assimilation within a global cosmopolitan class, thereby inducing a politics of location and positionality that determines their representation.

One particular reference to legal agency at the TWAIL conference warrants a brief mention here. An audience member raised a question to a panelist who presented a paper on the perils of legal education in Africa. The panelist, an African scholar based in the South, discussed issues such as institutional politics and resource constraints in her presentation. The interlocutor, an academic located in the global North, pondered why the Third World tends to refer to itself "in terms of lack" of resources and whether we

28 See generally, Austin Sarat \& Stuart Scheingold, Eds, Cause Lawyering: Political Commitments and Professional Responsibilities (Oxford: Oxford University Press, 1998); Stuart Scheingold \& Austin Sarat, Something to Believe in: Politics, Professionalism and Cause Lawyering (Palo Alto: Stanford University Press, 2004). Scholars have also assessed the ways in which these models travel to other parts of the world. The existence of these exports are acknowledged and often scholactivists are at the forefront of doing so. See Scott L Cummings \& Louise G Trubek "Globalizing public interest law" (2008) 13:1 UCLA J Int'1 L \& Foreign Aff 1.

29 International here denotes disciplinary knowledge that is generally or universally recognized. 
should invert this reference and focus on the positives instead. ${ }^{30}$ The scholar politely responded by saying what had been presented is, in fact, true based on her experience of teaching in her particular country.

The question was perhaps somewhat rhetorical: an invitation to think of a distant African nation beyond the truth claims of a scholar physically located in the Third World and to reconstruct those claims based on what the local agent cannot see. For many scholars who work in those Third World conditions, it would be difficult not to receive such a line of questioning with some skepticism. It is unlikely that no one in the Third World ever thought of solutions to these problems. This kind of interrogation may be misinterpreted as essentialism or at the very least unduly dismissive of material or structural conditions. ${ }^{31}$ It ignores the privilege of location and positionality implicated in the NorthSouth divide. Nevertheless, these questions are necessary reminders to keep engaging in conversations even among those who approach the existing international legal discourse in a critical vein. It also allows responses from scholars located in the Third World, thereby creating spaces through which they can shape how the Third World is represented, how its knowledge is produced, and how we understand its conditions.

Many TWAIL scholars have considered the conditions and politics of knowledge production in the Third World. Both Anghie and Gathii recognize the powerful international division of intellectual labour and the consequent politics of knowledge. ${ }^{32}$ Although a lot of TWAIL's contribution comes from many Third World scholars based in North America, critical perspectives of international law emanating from the geographical Third World do complement it. ${ }^{33}$ Many TWAIL scholars "have close connections and working relationships with, and are major participants of many locally grounded progressive movements, in many parts of the geographical third world." "34 TWAIL interrogates "the dominant discourses of international law, particularly within North America, Australia and Europe",35 in interdisciplinary ways. This is done along various axes of difference such as race, class, gender, sex, ethnicity, economics, trade, etc. ${ }^{36}$ Thus, TWAIL scholars "think of the third world less in geographical terms, and more in terms of TWAIL's agenda of advocacy of oppositional practices that challenges power hierarchies and how they work." ${ }^{37}$ Like Rajagopal and Santos et al., there is an emphasis on

30 This statement draws attention to the line of interrogation. It is based on impressions from interactions with other scholars from the Third World as well as personal observations at the event. The emphasis is on the comparable privilege and safer academic spaces in the Northern academy regardless of identity. The ethnicity or identity of the interlocutor (i.e., diaspora or native) is irrelevant.

31 Scholars of postcolonial theories have taken up debates on positionality and location at length. See Aijaz Ahmad, In Theory: Classes, Nations, Literatures (New York: Verso, 1994); Nivedita Menon, "Orientalism and After" (1993) 6:1 Public Culture 65; Arif Dirlik, "The Postcolonial Aura: Third World Criticism in the Age of Global Capitalism" (1994) 20:2 Critical Inquiry 328.

32 See Antony Anghie \& Bhupinder S Chimni, "Third World Approaches to International Law and Individual Responsibility in Internal Conflicts" (2003) 2 Chinese J Intl L 77; Gathii, supra note 9.

33 Gathii cites the contributions of Bhupinder Chimni and explicitly points out his location at the Jawaharlal Nehru University in New Delhi, India. See, Gathii, supra note 9.

34 Ibid at 47.

35 Ibid at 35.

36 Ibid.

37 Ibid at 48. 
decentering geography. This requires redefining the Third World in global terms that capture increasing inequalities in both the Global South and North. ${ }^{38}$

The Cairo conference has generated a series of timely and important publications on the theme of agency. ${ }^{39}$ Many of these echo similar calls for a deterritorialized Third World. This article readily acknowledges and agrees that pockets of Third World like conditions exist even in the Global North. This view dislocates and expands the location of suffering and discontent beyond the geographical Third World. It also helps overcome binary modes of thinking in terms of First and Third Worlds. However, such an approach obscures the location of, and issues surrounding, access, thereby discursively erasing the politics of place. ${ }^{40}$ Most debates about globalization are presented as a totalizing phenomenon, driven by global capitalist processes and a shrinking, interconnected world. Approaches like SCL offer new alternatives that uncover the potential embedded in nascent or marginalized legal practices within social movements. However, counter-hegemony, as envisaged by Rodríguez-Garavito and Santos, needs to operate both epistemologically and materially if it is to articulate and affect actual human conditions. ${ }^{41}$

Legal agency maybe be better understood by tracing the multi-scalar operation of agents back to concrete places, thereby bringing both geography and the state back into the discussion. Place-based perspectives take into account the contextual complexities of social and cultural locations of those who help construct social movements. They reveal the ways in which these agents resist power, very often embodied in the form of the state, and if necessary when to collaborate or avoid conflict. Such perspectives may also potentially minimize epistemic violence by connecting those who speak for the subaltern to a particular place, thereby preventing the erasure of agency. ${ }^{42}$ The politics of location and position, i.e., who is speaking and where one is speaking from, are central to accessing resources and mediums that help augment subaltern claims. Strategic accumulation of resources shifts the emphasis from who speaks for the subaltern to who will listen, focusing on impact and the outcome of claims. ${ }^{43}$ Considered from this perspective, legal agency operates on multiple registers, which include claims of subaltern people, states, and even intellectuals. Accordingly, legal scholactivists may act on behalf of subaltern populations, voice concerns of subaltern or Third World nations, and navigate the possibilities of the subalternization of their own voices when set against their dominant Northern counterparts.

\section{PORTRAIT OF A LAWYER}

38 See Prabhakar Singh, "Indian International Law: from a Colonized Apologist to a Subaltern Protagonist" (2010) 23:1 Leiden J Intl L 79.

39 See Third World Quarterly (2016) 37:11 Third World Approaches to International Law (TWAIL).

40 See Arturo Escobar "Culture Sits in Places: Reflections on Globalism and Subaltern Strategies of Localization" (2001) 20:2 Political Geography 139; See Prazniak \& Dirlik, supra note 3.

41 See Arif Dirlik, Shaobo Xie \& Fengzhen Wang, Dialogues on Cultural Studies: Interviews with Contemporary Critics (Calgary: University of Calgary Press, 2002) at 212.

42 See Prazniak \& Dirlik, supra note 3.

43 G Spivak, "Questions of Multiculturalism" in S. Harasayam, Ed, The Post-Colonial Critic: Interviews, Strategies, Dialogues (New York: Routledge, 1990) 77 [Spivak, “Questions of Multiculturalism”]. 
Kamal Hossain, lawyer, statesman and politician, is a household name in Bangladesh. He descends from a family of South Asian landed gentry that later turned to professionalization. Family members, many of whom included doctors, civil servants, judges and lawyers, likely influenced his career choice. Hossain was exceptionally meritorious as a student, a feat that earned him undergraduate opportunity in the US. He then pursued graduate studies at Oxford University where he also completed his doctoral degree. He was subsequently called to the English Bar by Lincoln's Inn in 1959. Hossain's career reached its zenith at home, responding to oppression and injustice. His foray into international legal scholarship and practice was inspired by the prevailing historical times - in response to the inequities produced by geopolitical conditions. Early on in his life, Hossain witnessed the external colonization of India (by Britain), where he grew up, and later the internal colonization of East Pakistan by West Pakistan. The injustice and deprivation generated by these moments had a profound impact on him. His doctoral research interests on state sovereignty and the United Nations [UN] Charter are early evidences of this.

\section{A, The Making of a Legal Scholactivist}

Hossain's arrival in the legal landscape of East Pakistan followed the footsteps of his predecessors and South Asian legacies of lawyer-politicians. Initially engaged in public and commercial legal practice during 1961-1971, he gradually stepped into politics. Hussain Shahid Suhrawardy, a lawyer-politician whose career dominated East Bengal politics of the 1940s and 1950s, was a major influence in Hossain's life. ${ }^{44}$ Hossain played a prominent role in the run-up to the war of independence. This entailed deploying his legal expertise to defend Bengali nationalist leaders. In one sense, he began his political career as a highly partisan lawyer. His legal career assumed political colour as he began to work with Sheikh Mujibur Rahman who was to become the founding father and the Prime Minister of independent Bangladesh. During the war, the Pakistani military regime arrested both Hossain and Mujib on charges of conspiracy and anti-nationalism. ${ }^{45}$ They were blamed for catalyzing the movement of East Pakistan's independence. Both of them remained in prison until the end of the war. The duo was released together and soon found themselves facing the herculean task of postwar reconstruction.

One of Mujib's great strengths in the formative years of state-building was to recognize and recruit expertise. He had, in his arsenal, lawyers and economists who not only protested the pre-war discrimination but also framed demands in ways that were intellectually sound. Later on, this approach served Mujib well in articulating self-determination to the international community. Hossain was one of Mujib's close confidantes. His expertise, along with contributions to the nationalist movement, earned him several ministerial positions including law, petroleum and foreign relations. The role of a statesman prepared Hossain for what later became a very successful career in international legal practice. More importantly, however, it brought him to the axis of power both within the state as well as on the global stage. Hossain was instrumental in establishing foreign relations of newly founded Bangladesh and

\footnotetext{
44 See Sharif Bhuiyan, Philippe Sands \& Nico Schrijver, "I Believe in the Power of Human Beings to be Agents of Change:' An Interview with Kamal Hossain” in Sharif Bhuiyan, Philippe Sands \& Nico Schrijver, Eds, International Law and Developing Countries: Essays in Honor of Kamal Hossain (Leiden: Brill, 2014); Kamal Hossain, Bangladesh: Quest for Freedom and Justice (Oxford: Oxford University Press, 2013). [Hossain, Bangladesh] Ibid.
} 
pursuing the UN for its recognition and membership. ${ }^{46}$ Initially, this proved difficult as Pakistan, from which it had just seceded, launched a campaign against its membership. China vetoed Bangladesh's membership to the UN. Recognition was crucial for Bangladesh. Without membership there would be significant challenges in mobilizing external assistance and resources for rebuilding the state and repatriating some 10 million refugees displaced by war. ${ }^{47}$ What followed is as much a product of historical circumstances as an extraordinary display of Hossain's sagacity in navigating international politics.

While pursuing UN membership, Hossain found himself among friends within the Commonwealth Secretariat. In the wake of Pakistan's threats to relinquish its own Commonwealth membership should Bangladesh be recognized, the Secretariat not only accorded it membership but also provided technical assistance based on the transfer of expertise at the new Bangladeshi government's request. ${ }^{48}$ The Commonwealth made available several leading international experts to support state building. Sir Kenneth Roberts-Wray and Richard Guthrie were commissioned to work with the Constitutional Drafting Committee in Bangladesh. Professor Daniel Patrick O'Connell advised on both state succession and maritime issues. Bangladesh pioneered in announcing contiguous and extensive economics zones and continental shelf, well ahead of the UN Conference on Law of the Sea in 1973. The Commonwealth framework made it easy for Britain to channel its support for recognition, as well as for Bangladesh to deal with then-prevailing territorial issues with India without appearing to encroach in India's internal matters. The technical assistance was especially useful for bolstering Bangladesh's capacity to negotiate with international organizations and claim its place in the international community.

During this time, Hossain and his colleagues were pressured by the World Bank to assume half of Pakistan's liabilities as a precondition to assistance. ${ }^{49}$ However, negotiations turned on several important factors. First, Professor O'Connell's opinion on state succession, which recommended an equal division of assets and liabilities between Pakistan and Bangladesh, carried enormous weight and credibility. The World Bank mission tried to invoke international law as a technical ground for acquiescing to liabilities. The expert opinion, which Bangladesh had secured from the Commonwealth, served as an effective rebuttal. Secondly, Bangladesh articulated its demands in terms of justice. Based on Hossain's advice, Mujib took a strong position against the unjust outcome of treating these liabilities as technical international law, especially considering the state itself came to exist in response to injustices. This framing was important. It called for a shift from a procedural emphasis in interpreting international law to a more substantive, equitable and outcome-based one. In so doing, it also questioned the virtues of international law should such an unfair outcome flow from its application. Ultimately, the World Bank yielded to these arguments supported by expert opinion. Later, Bangladesh took an equally strong position along similar lines against the Chinese veto, which subsequently led to the UN's recognition of Bangladesh in 1974.

46 Ibid.

47 Interview with Kamal Hossain by Dr. Sue Onslow (8 December 2014) on Commonwealth Oral History (2015) $<$ http://www.commonwealthoralhistories.org/2015/interview-with-kamal-hossain/>.

48 Ibid.

49 Ibid. 
There are other dimensions to the Commonwealth's support to Bangladesh. The Commonwealth Secretariat at the time was emerging as a venerable international organization with a structure much less bureaucratic than the UN. Its first two Secretaries-General were well-versed with North-South issues within international relations and deployed both institutional and personal diplomacy to resolve internal strains between its members. ${ }^{50}$ Bangladesh was arguably a case for the Commonwealth Secretariat to legitimize its own role as an international institution brokering between nations. The Commonwealth's contributions were based on prevailing geopolitics and its own institutional dynamics. However they were also the product of networks and relationships built on common interests, educational experiences and collegiality. Hossain recalls the importance of finding an ally in Arnold Smith, the first SecretaryGeneral of the Commonwealth Secretariat. ${ }^{51}$ Smith played an important role in catalyzing the international recognition of Bangladesh as a sovereign state. Incidentally, Hossain and Smith shared an alma mater. They were both Oxford University graduates, while Smith's successor Ramphal also shared commonalities with Hossain as both were trained barristers called to the English Bar. ${ }^{52}$ The Commonwealth association led to other opportunities for Hossain, which helped solidify his commitment to public international law.

Hossain's seminal contributions to international law and scholarship occurred mostly after 1975 following the assassination of Mujib. ${ }^{53} \mathrm{He}$ remained in self-imposed exile in the United Kingdom for six years, where he resumed legal research and revived his legal career. ${ }^{54}$ Initially, he took up a research fellowship funded by the Commonwealth. He worked on the then-emerging issues in the petroleum sector, resulting in a major publication. ${ }^{55}$ It helped position him as an authority in the field. This was an important outcome as it led to further international work. ${ }^{56} \mathrm{He}$ became an official Commonwealth resource person commissioned on several missions, including those relating to state-building. ${ }^{57}$ Soon, he was able to leverage his petroleum sector experience to diversify to international practice. Hossain had the opportunity to appear on behalf of the Qatari government in an investment arbitration case against a

50 Margaret Doxey, The Commonwealth Secretariat and the Contemporary Commonwealth, (Palgrave Macmillan: London,1984) 15-39.

51 Commonwealth Oral History, supra note 47.

52 See Doxey, supra note 50.

53 For a representative sample, see Kamal Hossain, Ed, Legal Aspects of the New International Economic Order (Oxford: Bloomsbury Academic Collections, 1980); Kamal Hossain \& Subrata Roy Chowdhury, eds, Permanent Sovereignty Over Natural Resources in International Law: Principle and Practice (London: Pinter Publishers, 1984); Kamal Hossain, Ed, Human Rights Commissions and Ombudsman Offices: National Experiences throughout the World (Leiden: Martinus Nijhoff, 2000); Kamal Hossain "Evolving principles of sustainable development and good governance" in Sustainable Development and Good Governance (Dordrecht: Martinus Nijhoff, 1995) 15-22; Bhuiyan, Sands \& Schrijver, supra note 44.

54 Bhuiyan, Sands \& Schrijver, supra note 44 at 23.

55 Kamal Hossain, Law and Policy in Petroleum Development: Changing Relations between Transnationals and Governments (New York: Nichols Publishing, 1979).

56 Hossain went to China as an expert on a UN mission as a direct result of his scholarly contribution to the petroleum sector. Other missions soon followed this one to various Commonwealth countries on energy-related matters. See Commonwealth Oral History, supra note 47.

57 Hossain has served in Commonwealth advisory commissions and has worked in areas other than petroleum. His association with the Commonwealth also led him to countries like Cameroon and Gambia on assessment missions for democracy and rule of law. Ibid. 
German oil company. ${ }^{58}$ Hossain's legal team won the case, which was an inaugural victory for a state against a major oil company. Through this case, Hossain's network of colleagues expanded to include eminent lawyers like Oscar Schachter and others-opening the door to what came to be considered an invisible college of lawyers. ${ }^{59}$ Subsequently, Hossain also flourished as an arbitrator. Hossain eventually returned to Bangladesh, which continues to be his base. His portfolio extends to both national and international work, politics, advocacy and other civil society engagements.

\section{B. Injustice and Emancipation: Dealing with Dichotomies}

Quite early on in his international career, Hossain recognized the inequities of the international legal order. It appeared neutral in its face but was substantially favourable to the West, with much of its content, perhaps unsurprisingly, also authored by its agents, i.e., Western lawyers. This was in order to protect Western investments abroad and minimize local adjudication of cases in the national forums of Third World states. ${ }^{60}$ In the petroleum sector, the states and major foreign investors did not share equal bargaining power. In addition, their transactions required technical as well as organizational competence, which Third World host states lacked. Investors would often deploy disingenuous means to secure favorable contracts. ${ }^{61}$ These states also inadequately understood their contractual obligations as well as arbitral forums and jurisdictions that were to adjudicate their disputes. ${ }^{62}$ These asymmetries and the lack of a level playing field between the powerful and the weak has been a consistent theme in Hossain's work.

Hossain is part of a generation that believed in post-World War II ideals that framed demands of freedom from colonialism as injustice and claimed equal rights. ${ }^{63}$ In recent years, he observes a departure from these ideals and the reappearance of neo-colonialism. ${ }^{64}$ His observations are based on a variety of sources. For instance, trade and investments contributed to global growth but also defined economic activity by market fundamentalism. In turn, this has accentuated inequalities by prioritizing profiteering over equity, justice, sensitivity to human rights, and protection of the environment. ${ }^{65}$ This, he claims, pervades rich and poor countries alike as the global economic order is increasingly under elite capture. ${ }^{66}$ Hossain also questions the efficacy of the modern nation state as mass electoral politics has

58 Bhuiyan, Sands \& Schrijver supra note 44 at 24.

59 See Oscar Schachter, "Invisible College of International Lawyers" (1977) 72 Nw UL Rev 217. For its most recent reference and usage of the term, see Sayed, supra, note 27.

60 Ibid at 24 .

61 See Bhuiyan, Sands \& Schrijver, supra note 44 at 25.

62 For an account of the history of developing countries and investment treaties in which governments in many developing countries overestimated the economic benefits of those agreements and practically ignored their risks, see Lauge $\mathrm{N}$ Skovgaard Poulsen, Bounded Rationality and Economic Diplomacy: The Politics of Investment Treaties in Developing Countries (Cambridge: Cambridge University Press, 2015).

63 Bhuiyan, Sands \& Schrijver, supra note 44 at 25.

64 Ibid at 26.

65 Ibid.

${ }^{66}$ Ibid. 
been skewered to perpetuate elite domination. ${ }^{67}$ This is partly informed by his earlier work as an election observer in countries like South Africa. Drawing from his professional experience through the Commonwealth, he points to the increasingly functional role played by elections in offering the state a "fig leaf". ${ }^{68}$ In some cases, elections have legitimized authoritarian governments through an appearance of democracy. Hossain along with some of his colleagues have pushed back and resisted the "parachuting" in of election observers in what they perceived to be fake or voterless elections. ${ }^{69}$

Despite these disappointments, Hossain continues to consider international law and institutions to be effective weapons against injustice and oppression. While working as the UN Special Rapporteur on the human rights situation in Afghanistan, he found, within international law, particularly potent responses against the Taliban from 2001 to $2003 .{ }^{70} \mathrm{He}$ addressed the UN Security Council on the status of refugee children. Initially, he found the UN to be disinterested. During one of his addresses to the Security Council, he was asked, "Do you think these primitive people understand human rights?", ${ }^{71}$ to which he answered, "you will be surprised how many people who are deprived of rights understand the value of those rights, more than you and I, who take it for granted." ${ }^{, 72}$ By Hossain's account, human rights for Afghans meant security against both arbitrary punishment and denial of their basic rights and expectations. The Security Council's question to him arguably reveals elements of othering and racialization within international institutional settings. It is also perhaps indicative of the ways in which uneven histories of the powerful and the weak, international relations and politics permeate such institutions. Hossain, however, framed such questions as cultural difference instead, predicating them upon a lack of understanding of certain cultures. ${ }^{73}$ Accordingly, he drew attention to the institutional avenues of advocacy that helped overcome these deficits and advanced his cause (and that of the Afghan refugees), indicating a strategic approach. ${ }^{74}$

Hossain went on to adopt some unconventional strategies during this assignment. He collaborated with Iranian film director Mohsen Makhmalbaf in Tehran to film a documentary on Afghan refugee children called Alphabet, which was later distributed with the help of UNICEF. ${ }^{75}$ The film was a strategic campaign in an effort to incentivize the Security Council and other stakeholders. As an insider, he understood the political dynamics within international institutions and believed that with the right kind of incentive and representation, such advocacy could translate into action. Having lived through Third World struggles, he was also perhaps acutely sensitive to the values of liberty. From this perspective, freedom is priceless, whether one is civilized or presumed primitive. Taking a stand against the Security Council may have also in some ways raised his profile, serving his professional ambitions. However, it also demonstrates his strategic use of institutional avenues that can further Third World causes.

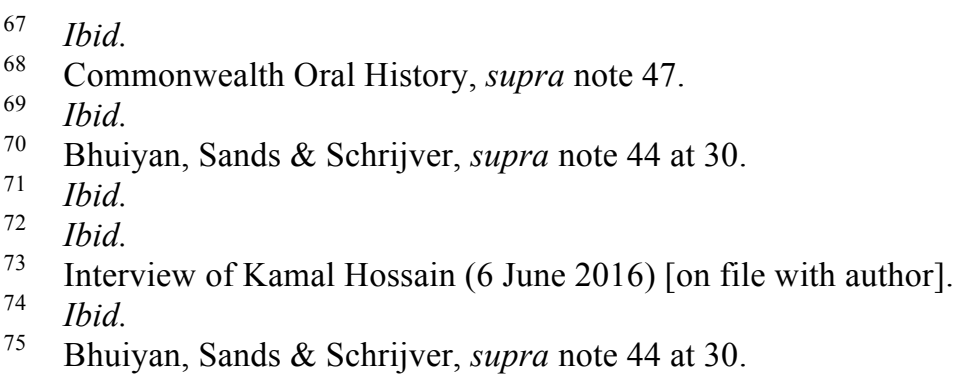


Hossain seems to believe in the efficacy of institutions in securing positive outcomes so long as they are grounded in principles of human rights and rule of law. ${ }^{76}$ Though he remains critical of their links to structural injustices, Hossain's predilection for institutional solutions authenticates his belief in law's duality as both power and emancipation.

The recourse to institutions is also perhaps part of the legal tradition and training among South Asians that can be traced back to Hossain's early career. ${ }^{77}$ Although he was an indispensable intellectual support at certain historical junctures of Bangladesh, he has not been a grassroots or frontline revolutionary. Politically he has erred on the side of legal avenues to challenge power, especially when confronting the state. This is where his scholactivistic leanings have been manifest. Hossain, along with other lawyers, helped mount a case against the military-backed government in the late 1980s, successfully challenging a constitutional amendment in the Supreme Court. ${ }^{78}$ This created a strong position for the legal profession in the field of state power. Subsequently, Hossain was an important ally for the state in authoring a constitutional compromise in the wake of Bangladesh's democratic transition in $1991 .^{79}$ These historical moments generated political opportunities for resistance and reform through law. In other instances, though, the absence of political will meant that legal solutions provided stopgap measures and deradicalized subaltern demands. ${ }^{80} \mathrm{~A}$ strong emphasis on institutions also meant that much of his focus remained top down or at the policy level. Hossain's litigation choices included relatively limited subaltern cases. In his long and illustrious career, housing rights cases have been Hossain's most recent and one of his few engagements with directly dealing with rights of the poor. ${ }^{81}$ Instead, he

76 Commonwealth Oral History, supra note 47.

77 The only precedence for extra-legal means deployed by lawyers may be found in Gandhi's largely unsuccessful attempt to galvanize the bar in boycotting British Indian courts. This was later followed by a successful non-cooperation movement once popularized beyond legal actors and institutions. Lawyers seem to be strategic, cautious and usually operate within institutional means. For an account of Gandhi's court boycott movement, see James Jaffe, Gandhi, Lawyers, and the Courts' Boycott during the Non-cooperation Movement (2016) [unpublished] [on file with author].

78 See Anwar Hossain Chowdhury v Bangladesh (1989) 41 DLR (AD) 165. For a discussion on how this case came to be instituted in the Supreme Court of Bangladesh, see Cynthia Farid, "New Paths to Justice: A Tale of Social Justice Lawyering in Bangladesh" (2013) 31 Wis Intl LJ 421.

79 This was done through a constitutional amendment to reach a political compromise between political parties for elections and transfer of power through a transitional or caretaker government. See M Jashim Ali Chowdhury, "Elections in 'Democratic' Bangladesh" and Ridwanul Hoque, "The Judicialization of Politics in Bangladesh" in Mark Tushnet \& Madhav Khosla, Eds, Unstable Constitutionalism: Law and Politics in South Asia (Cambridge: Cambridge University Press, 2015).

80 This is nowhere more evident than in slum eviction cases which are demonstrative of the limits of law. Hossain has been involved in the legal aspects of these cases to some extent. However, successive governments have been unwilling to adopt a long term housing policy for the urban poor, which leaves slum residents vulnerable to violent evictions. Strategic mobilization and timely legal assistance are, therefore, only temporary solutions. See C Farid, T O'Neil \& C Valters, "Doing Legal Empowerment Differently: Learning from Pro-poor Litigation in Bangladesh", online: (2015) Overseas Development Institute $<$ http://www.odi.org/sites/odi.org.uk/files/odi-assets/publications-opinionfiles/9585.pdf>.

81 Hossain has appeared in a number housing rights cases filed by legal aid services NGOs. For a discussion of these cases, see Farid, O’Neil \& Valters, ibid. 
directed his efforts towards institutional initiatives of legal aid for the poor through the Bangladesh Legal Aid and Services Trust_ — which he helped found in the 1990s with Ford Foundation funding. ${ }^{82}$

This kind of faith in institutions is likely the outcome of law's historical relationship with Third World lawyers, both in response to colonial rule and decolonization when international law and the development discourse rose to prominence. Such confidence in institutions, somewhat contradictorily, necessitates acquiescing in the very structures one seems to be resisting. ${ }^{83}$ The Third World's entry into the international legal order was to acquire social and political membership and galvanize "development" for nation building to catch up with the developed world. ${ }^{84}$ Over time, the inequities of this system became apparent to Third World lawyers. ${ }^{85}$ In one interview, Hossain referred to the myth of Sisyphus, who keeps pushing a boulder atop a mountain knowing it may very well slip down. According to Hossain, the "human spirit lies very much in the act of pushing it up and should it begin to roll down, gathering strength to renew efforts to push it up again." ${ }^{, 6}$ It is no accident that Keba M'baye and Mohammad Bedjaoui used similar references - pointing towards a shared ideal and optimism among earlier generations of lawyers. ${ }^{87}$

This kind of idealism, shared by many such international lawyers from the Third World, is grounded in law's transformative potential for the Third World. ${ }^{88}$ Law's legitimation of power as well as liberating potential are part of the lived experiences of the Third World. There continues to be a dialectic between an apparent discontent with international law and the persistent involvement of these same lawyers in international dispute resolution forums as practitioners, arbitrators and so on. It points towards a dualist faith in law as both power and resistance. Examining the process through which a Third World lawyer "internationalizes" may shed some light into what contributes to such idealism in legal scholactivists.

\section{SCHOLACTIVISM AND CHALLENGES OF THE LEGAL FIELD}

Hossain's career trajectory displays many of the propositions put forward by Dezalay and Garth. Positioning and success within the international legal field require symbolic capital. Hossain entered the international legal field with very specific forms of such capital. He inherited cultural capital by virtue of familial pedigree and (later acquired) through education, and accumulated social capital through his role in domestic legal practice and in politics as a statesman. A further example of habitus and symbolic capital may be found in Hossain's ability to diversify beyond legal practice and dispute resolution

82 Hossain chairs several other initiatives, including South Asian Institute of Advanced Legal and Human Rights Studies (SAILS) and Bangladesh Institute for Legal and International Affairs (BILIA).

83 See Sundhya Pahuja, Decolonising International Law: Development, Economic Growth and the Politics of Universality (New York: Cambridge University Press, 2011).

84 See Upendra Baxi, The Crisis of the Indian Legal System. Alternatives in Development: Law. Stranger Journalism (New Delhi: Vikas, 1982).

85 See Rajagopal, supra note 10; Pahuja, supra note 83.

86 See Bhuiyan, Sands \& Schrijver, supra note 44 at 28.

87 See Karen Mickelson, "Rhetoric and Rage: Third World Voices in International Legal Discourse. (1998) 16:2 Wis Intl LJ 353 at 355, citing Keba M'baye, «Le droit au développement comme un droit de l'homme», (1972) 5 Revue des droit de l'homme 505 ; Mohammed Bedjaoui, Towards a New International Economic Order, (New York : Holmes \& Meier : 1979) at 84.

88 Ibid. 
forums. He was one of the signatories of the founding charter of Transparency International in 1993. Hossain still remains a central civil society figure and has been quite influential in NGO and grassroots movements in Bangladesh. ${ }^{89}$ These different species of symbolic capital, acquired through education, political career, professionalization, and participation in the international legal field, translated into convertible currency for economic benefit as well as strategic influence within the legal field. In turn, he was able to leverage such capital to further his causes.

By Dezalay and Garth's account, Hossain's activism will not sustain without offshore support and leadership from powerful and politically-connected elites. However, it would be simplistic to suggest Hossain's success and commitment to social justice are solely the products of external support or powerful elite connections. In the early years of Hossain's career, he contributed to creating a place for the profession in the field of state power. Later, his efforts were directed away from the state. His foray into civil society work reflects his doubts about the state's transformative potential. Hossain's ability to sustain his causes through new mediums is not just the result of resources at his disposal but is also a testament to his commitment to them. He has undoubtedly led an ambitious legal career and perhaps many of his decisions were geared towards serving it. Nevertheless, he also remained committed to his causes despite significant personal and political costs. There were palace wars involving local politics, the state and the legal field but through them he continued to pursue alternative forums, networks and mobilizing strategies to realize his social justice goals.

Bangladesh's historical and political developments have been both resourceful as well as limiting for Hossain's career. Bangladesh is post-colonial with a long history of internal colonization and military rule. ${ }^{90}$ Colonial era investments in law were largely disrupted by the two founding moments of the former East Bengal in its transition to independence in 1947 and 1971, respectively. There were ebbs and flows in law's symbolic value at different times in Bangladesh's history. Despite a Muslim majority population, Bangladesh was founded on secular ideals. This was partly possible due to its radical origins and the embodiment of secularism as a founding principle in the Constitution of Bangladesh (of which Hossain is one of the principal authors). In this case, lawyers proved to be not just carriers of law but also architects of ideology. Political debates are still constructed by elites and non-elites alike by invoking many of these enduring ideologies. Subsequently, long periods of authoritarian rule limited law's function to strictly positivist uses and restricted the independent functioning of legal institutions. Lawyers rose to prominence again during Bangladesh's democratic transition from military rule in 1990. The political crisis of this period drew the legal elites into the political process. Consequently, many such elites played a substantial role in brokering a settlement between political actors for holding elections and transitioning to power.

The legal profession in Bangladesh has, by and large, enjoyed institutional autonomy. It has an English speaking elite and many of its intellectuals were trained in Europe, North America and the former Soviet Union, displaying a crossroads of global influences still at play. ${ }^{91}$ Lawyers have

89 For an account of lawyers and their role in NGO and grassroots movements in Bangladesh, see Farid, O’Neil \& Valters, supra note 80.

$90 \quad$ See Hossain, Bangladesh, supra note 44.

91 I am grateful to Frank Munger for some of these observations on globalization which informs my analysis. For an analysis of legal elites and civil society in Bangladesh, see Farid, supra note 80. 
successfully defended the autonomy of law. It has helped strengthen the Supreme Court's role in guarding the Constitution and upholding public interest. This demonstrates the contributions that lawyers can make in building the legitimacy of law. Hossain, in particular, has been one of those lawyers who contributed to national development by acting as an intermediary between the local and the global and by judicializing politics when confronting the state.

\section{A. State Power and Elite Lawyers}

The state is an important consideration when assessing scholactivism and its relationship to internationalization. The ways in which one confronts and negotiates with other political actors such as the state affects the accumulation of symbolic capital. The state can also be a push factor towards transnational forums for seeking alternative sites of resistance and, in extreme cases, even prove to be a disincentive for scholactivism. Hossain's frequent and prolonged absence from the country due to international commitments has witnessed a gradual distancing from domestic constituencies. The dystopian state of domestic politics and its relationship to the legal field, coupled with the availability of alternative forums for both professional and scholactivist practices, may have pushed Hossain's interests away from national matters.

Despite his many accolades in legal practice, Hossain shares an ambivalent relationship with politics at home. In Bangladesh, Hossain's relationship with the liberation movement party, Awami League, soured in the nineties and it continues to be arduous. This eventually resulted in a formal split, leading to Hossain's alternative party Gono Forum. ${ }^{92}$ However, it gained little traction, owing largely to the historical dominance of two major political parties in Bangladesh.

Relationships with political actors can often translate into professional gains or costs. Accordingly, political allegiance and patronage networks can facilitate or constrain success in the legal field. Hossain's involvement in international arbitration in which Bangladesh was a party is a case in point. ${ }^{93}$

Petrobangla, the petroleum agency of the Bangladeshi government during a brief hiatus of democratic rule in 2007-2008, approached Hossain with instructions to appear in an arbitration hearing. ${ }^{94}$ Their proposed instructions to Hossain required him to conclude the closing formalities of negotiating legal costs in a dispute with the energy corporation Chevron. Petrobangla and Chevron had agreed to a production-sharing contract for the purchase of gas from the Jalalabad gas field in Bangladesh. Chevron was utilizing Petrobangla's pipeline to transmit gas from the Jalalabad field into the state-owned national gas network. Hence, Petrobangla deducted a four percent wheeling charge from its payments to Chevron. Subsequently, Chevron moved the dispute to arbitration. Bangladesh had failed to adequately respond or defend the case under previous political party regimes due to inadequate legal advice from government-appointed lawyers. The case came to Hossain at a very late stage and was weeks away from an award. Initially he refused to accept the brief on account of this delay. He considered the act of

92 Hossain split from the Awami League due to various reasons which included a lack of internal democracy within the party and personal differences. See Ali Riaz, "Political Parties, Elections and the Party System" in Ali Riaz \& Mohammad Sajjadur Rahman, Eds, Routledge Handbook of Contemporary Bangladesh (London: Routledge, 2016).

93 Chevron Bangladesh Block Twelve, Ltd and Chevron Bangladesh Blocks Thirteen and Fourteen, Ltd v People's Republic of Bangladesh, ICSID Case No ARB/06/10.

94 Interview, supra note 73. 
sending a new lawyer to settle costs at this late stage a matter of national pride and prestige. Bangladesh, as a nation, would appear to be pleading to the international community for handouts. ${ }^{95}$

Following several appeals from Petrobangla, Hossain reviewed the case, hopeful about reviving it. He mounted a defence in which he invoked the manifest asymmetries in the negotiations between Bangladesh and Chevron. He strongly defended the delays in securing effective representation by highlighting the state's relative weak capacity to organize its resources and locate expertise in these highly technical cases. The tribunal was convinced by these arguments and eventually the matter was decided against Chevron. It ultimately saved Bangladesh millions of dollars. ${ }^{96}$ Beyond the legal arguments of the case, Hossain's social position in the international legal field was probably a significant factor in this case. He was able to leverage his international contacts and professional colleagues and swiftly put a team together. ${ }^{97}$ His reputation in the field likely contributed to convincing the panel of arbitrators to let him make his case despite such inordinate delay. It is worth mentioning that Hossain's involvement in this case was accidental. The inadequacies of the prior legal representation of Petrobangla in the Chevron case was partly the result of limited technical expertise, though the state typically plays a significant role in recruiting such experts. Ruling parties often sustain their networks of patronage through regime-favoured lawyers as opposed to technical experts. The inadequacies of legal representation may be considered to be such an indication. The case continued for several years before reaching Hossain almost at the final award stage of the proceedings. The political vacuum created by the democratic crisis of 2007-2008 led to a reshuffling of the administration and removal of certain political actors. This may have prompted the shift towards technical expertise.

Political opportunities typically determine whether the state will be an ally or opponent. Contemporary international legal discourse still considers the state to be the executor of rights. Social movements can help reconstitute and democratize its structural aspects but cannot replace its function. Legal scholactivists, given their strategic approaches, are not in opposition to the state but recognize it as an important factor influencing the outcome of their work. Hossain's experience shows that he has worked within the state as well as outside it. He organized through alternative forums when necessary, which involved relying on international networks of solidarity and other professional associations. These were important in realizing many of his goals. He continues to consider citizen activism critical to reempowering people, while also recognizing its potential to draw the ire of the state. ${ }^{98}$ Hossain recognized the tensions between sovereignty, rights and social movements early on in his career. Accordingly, he has attempted to channel popular demands into institutional endeavours.

In addition to political actors, the legal profession itself impacts scholactivism. Lawyers of Hossain's generation were able to create a place for the legal profession within the field of state power. In recent years, however, state patronage is increasingly influencing professional success. Contentious annual elections of bar associations are now sponsored by political party tickets, replacing traditional forms of

95 Ibid.

96 See, Scimitar Exploration Limited v. Bangladesh and Bangladesh Oil, Gas and Mineral Corporation, ICSID Case No. $\mathrm{ARB} / 92 / 2$.

97 Interview, supra note 73.

98 See Bhuiyan, Sands \& Schrijver, supra note 44 at 28. 
symbolic capital. ${ }^{99}$ Lawyers who are perceived to be affiliated with the ruling party or other powerful political actors can generally expect more business and influence. Hossain was involved in bar association elections earlier in his career. It was at a time when the bar as a collective was a formidable independent force. It consisted of politically connected but very well-educated lawyers. Since then, there has been a decline in legal education and training. Though foreign degrees are still coveted, their benefits do not seem to be translating locally. The bar appears to be political insofar as claiming allegiance to power, i.e., political parties, is concerned. It has limited engagement with reform and even less with subaltern issues. As a result, alternatives have developed through which many legal elites organize under the umbrella of civil society and various NGO initiatives. ${ }^{100}$ The boundary between the bar and these diverse activities, however, is a porous one as these sets of elites frequently combine legal practice with social justice work. They also operate through networks and associational efforts. Hossain was one of the pioneers of this alternative trend.

Scholactivism has led to an onslaught of public interest work mostly through institutional routes of NGOs, think tanks and watchdogs. This kind of work encompasses various social justice issues, including human rights and access to justice. ${ }^{101}$ These replaced traditional service delivery functions of NGOs and offered alternatives to knowledge production through policy work. However, maintaining consistency in multiple forums is a tall order. Most institutions are dependent on foreign funding and centre on prominent individuals. Often, cultures of deference and social hierarchies can have an impact on the internal democracy of these institutions. Thus, sometimes such institutions are unable to thrive, as political autonomy and funding constraints determine impact. This is not to suggest a deliberate role on the part of founders of institutions. Founding and sustaining any initiative requires a combination of finances, collective effort, capable human resources, and strong research support-these are difficult to combine in the Third World. Accordingly, lawyers who resort to scholactivism struggle with a constant tension between producing work that is academically rigorous versus that which has political impact. ${ }^{102}$ This is further complicated by the doctrinal orientation of legal training in Bangladesh.

The legal academy, coupled with traditions and hierarchies embedded in the professionalization of the bar, entrenches formalist attitudes towards law and its reformist potential. Social relationships within the legal field also maintain a strict and conspicuous hierarchy based on seniority rather than peer group. Consequently, junior lawyers often reproduce similar tropes and expectations from the legal profession. Many view the profession as a stepping stone to a political platform. Visibility and success in the domestic field through the accumulation of capital can facilitate access to international resources and clientele. However, most law firms with such lucrative clientele tend to operate as one-person shows. Though qualified and successful senior lawyers run these outfits, they can often monopolize the field. ${ }^{103}$ The state also constrains some of these opportunities by favouring lawyers who are considered to be regime loyalists. Inclusion within the upper strata of the legal field is policed through certain political,

99 See Farid, O’Neil \& Valters, supra note 80.

100 Ibid.

101 Ibid.

102 See Borras, supra note 4.

103 This kind of structured practice is also noted in other countries such as Egypt; see Dezalay \& Garth, Dealing in Virtue, supra note 13. 
social and professional criteria. Affiliations with political actors influence upward mobility but other informal factors and hierarchies within the profession may also regulate it. For example, the International Law Association [ILA] chapter for Bangladesh, which Hossain helped launch, has a limited number of members. ${ }^{104}$ It includes some of the most eminent lawyers and judges in the country. Hence, inclusion of aspiring members likely depends on qualifiers such as relative cultural and social capital, institutional and international affiliations and so on.

Lawyers like Hossain are often trapped between their roles as private scholar, practitioner and public intellectual. Domination in multiple fields has the potential to cement the perception of lawyers from his generation as "clubby and elitist with no real connections with the most important mass struggles". ${ }^{105}$ In the case of South Asia, professionalization in law is historically related to the vertical mobility of elites. ${ }^{106}$ Actors who navigate the local and the global legal field with as much ease as Hossain have occupied elite positions and this transnational space is structured in ways that reproduce the status quo. Legal agents are, by definition, legal elites, though a distinction needs to be made here between elite and elitist. Many important conversations about international law, human rights, and poverty do, after all, often take place in elite surroundings in classrooms and conference halls of reputable international universities and institutions. Accordingly, the elite charge may be unavoidable although one may be positioned as an elite without being elitist.

Historically, internationalism among elite lawyers was important in the shaping of nationalism in South Asia. There is ample evidence of the connection between international (colonial) legal education and anti-colonial or nationalist movements in British India and other colonized places in the first half of the twentieth century. ${ }^{107}$ South Asia in particular has a storied tradition of professionals who met through these educational experiences. Hossain acknowledges the strong links among professionals, which was particularly true of lawyers pursuing the English bar. ${ }^{108}$ These cosmopolites found in law a means to enter public life and through the decolonization experience a way to forge strong networks of solidarity. As a statesman, Hossain's contributions to the movement for the New International Economic Order is widely acknowledged and one can see the value of these networks when examining his accomplishments. ${ }^{109}$ However, the meaning of internationalism or global cosmopolitanism has changed since Hossain's generation.

Due to historical reasons, networks like those cultivated by Third World lawyers through their Inns of Court association were tied to nation-building projects. This has changed as both educational experiences and associational efforts are increasingly more diffused. There may be some overlap

\footnotetext{
104 Limited membership seems to be the case throughout the region, Pakistan has 25 and Nepal 22 members respectively; though India has the largest number totaling 97 members. See online: International Law Association $<\mathrm{http} / / \mathrm{www}$.llahq.org/en/branches/index.cfm>.

105 See Rajagopal, supra note 10 at 20.

106 See Dezalay \& Garth, Dealing in Virtue, supra note 13; Sharafi, supra note 23.

107 See Janaki Bakhle, "Savarkar (1883-1966), Sedition and surveillance: The rule of law in a colonial situation" (2010) 35:1 Social History 51; Sumita Mukherjee Nationalism, Education and Migrant Identities: The England-returned (London, Routledge, 2009).

108 See Commonwealth Oral History, supra note 47.

109 See Sornarajah, Muthucumaraswamy. "The Return of the NIEO and the Retreat of Neo-liberal International Law." in Bhuiyan, Sands \& Schrijver, supra note 44.
} 
between those working on human rights issues and other areas of public international law for instance, but these are not predicated upon a monolithic project of solidarity among Third World nations. Instead, networks increasingly form around issues and specialized sub-fields. There are obvious advantages to this fragmentation as it shifted the focus away from nation states to people and onto specific issues like human rights, the environment, etc. International networks of lawyers like the ILA and others increasingly facilitate professional access and can in some instances provide the means to bypass or work around the state and promote transnational cooperation and solidarity. The agility with which lawyers like Hossain have been able to move across scales of national and international forums are exceptional case studies. For many lawyers within the Third World, structural constraints serve as significant barriers to access.

\section{B. Internationalization and Academic Dependency}

Internationalism has consistently sparked new transformative imaginaries in post-colonial South Asia - complementing nationalism with developmentalism. ${ }^{110}$ This follows a logic of western modernity and contributes to political and cultural imperialism by reinforcing a hierarchy between dominant (international) and subaltern (local) knowledge and expertise. ${ }^{111}$ For many countries of the Global South, including Bangladesh, internationalization occurs through certain push and pull factors. Legal elites tend to traverse a transnational space where they encounter international law through private commercial work involving international transactions or global corporations or through the kind of work with a more public orientation such as international development, NGO-based or internationally-funded research or human rights programs. There is a push towards internationalization in the field generally through the leveraging of foreign degrees, membership in international associations, and invocation of international human rights ideals. On the other hand, there is a consistent pull to the cosmopolitan centre.

Scholars study and eventually move to universities of the Global North for want of better opportunities and the ability to publish in reputable journals in the North, lawyers fixate on international practice and attach themselves to regional or global hubs located in Asia and Europe, and human rights activists justifiably find refuge in environments that respect their freedoms. ${ }^{12}$ Viewed this way, internationalization is both a material and a discursive construct. It highlights a distinctive aspiration of Third World scholars to access the global village, but in so doing they must confront the complicated realities of the geographical Third World. Legal scholactivists strive to get subaltern voices heard from geographical locations while competing for access within the international legal field to further their claims. As a result, knowledge about international law vis-à-vis the Third World is reproduced and provincialized based on Western understandings while simultaneously requiring the Third World lawyer to universalize under the dynamics and duress of the field she navigates. ${ }^{113}$

110 See Pahuja, supra note 83.

111 See Dirlik, Xie \& Wang, supra note 41.

112 The reasons for moving from one hemisphere to the other can be endless and are not under examination. Instead, this

South to North migration of scholars is affirmed as a matter of fact.

113 See Dipesh Chakrabarty, "Provincializing Europe: Postcoloniality and the Critique of History" (1992) 6:3 Cultural Studies 337. 
Internationalization is a significant means for accumulating symbolic capital in Bangladesh. With a growing middle class, more students can now afford an international education. In particular, institutions offering gateways to the once common South Asian tradition of securing calls to the English bar have proliferated. ${ }^{114}$ Both international education and command of the English language appear to be markers of cosmopolitan status, which may be leveraged for success in the field. However, there are inherent problems with this kind of provincial turn to internationalization. Mechanisms for localizing this acquired knowledge, i.e., academic infrastructure, remain largely inadequate. Internationalization enhances social capital but the Bangladeshi experience shows that in some cases it can be a disincentive, pushing lawyers away from the domestic legal field. As a result, individual success does not always translate into developing the field or institutionalizing greater access for others in the long term.

A persistent emphasis on internationalization, coupled with academic dependency on foreign concepts and methods, is out of sync with domestic juridical development. Local graduates are at a disadvantage due to the conventional and insular nature of the academy that views its function simply as a gateway to legal practice as opposed to its social function. A law graduate with an international degree will still need to learn local laws and processes but, given the state of legal academia and regulation of legal education, there is very little intellectual and institutional support for this transition. In Bangladesh, the tradition of qualifying as an English barrister remains in vogue. It may assist in the acquisition of status and general skills like advocacy, drafting, etc. but it does little to inspire reflection on the social impact of law. The redundancy of the English bar for development of the domestic legal field is yet to become apparent but it is certainly stratifying the legal profession into those with status (i.e., barristers) versus those without. The English bar has obvious credentialing benefits as it leads to acceptance among similarly-qualified peers and can signal certain assumptions of a superior lawyer to potential clients. ${ }^{15}$ To some extent this is in contrast to the divergent trend in neighbouring India. The quasi-protectionist Indian legal market has led to investments in national law schools. As a result, these schools are comparatively strong contenders when it comes to graduate placements and credentialing. Internationalization is still influential in India, though it seems to be continuing in newer hegemonic forms. ${ }^{116}$

Internationalization also poses challenges for the legal academy in Bangladesh. Postgraduate degrees from European or North American universities in subjects such as air and space law, intellectual property and even international law train students in conventional concepts that are applicable to a very different set of realities than what they might find if and when they return. It disenchants those

114 For its prevalence in Bangladesh, see Farid, O'Neil \& Valters, supra note 80.

115 This signaling to clients is echoed by one of Hossain's associates Moin Ghani. Ghani decided to pursue the English bar some years after his graduate studies, with several years of practice back in Bangladesh in between. Having attended the London School of Economics for both graduate and undergraduate studies, his decision to return to England for the bar was to a large extent motivated by the value of credentials. It reflects how deeply entrenched this tradition has become and how, among other considerations, clients value these lawyers somewhat more seriously than their counterparts on the basis of these credentials alone. See interview notes with Ghani (6 June 2016) [on file with author]. For a discussion on credentialing in the case of Indian lawyers, see Swethaa Ballakrishnen "Homeward bound: What does a global legal education offer the Indian returnees?" (2011) 80 Fordham L Rev 2441.

116 For a discussion on the rise of Indian lawyers pursuing LL.M. degrees in American law schools, see Swethaa Ballakrishnen, Ibid. 
interested in teaching these subjects as these disciplines are at very nascent stages within the domestic field. Though these academics, by virtue of these qualifications, can enhance the state of the field from a local perspective, the disjunction between their academic training and social realities is difficult to reconcile. This kind of self-perpetuating academic dependency may prepare the aspiring local law graduate for the global marketplace but ultimately fails to inculcate social reflexivity on pressing issues confronting their respective societies. ${ }^{117}$ In other words, such environs may not be conducive to the production of legal scholactivists. Within South Asia, India is witnessing a rising trend of global as well as privately-funded law schools with international affiliations. These are gateways to international education for students but also serve as opportunities for collaboration among academics of the global North and South. Many major conference venues have also shifted to new regional academic centres with international affiliations. Such collaborations are productive for cross-border scholarship as well as cultivating networks. They can also, arguably, legitimate the social status of individual scholars from both the North and the South who are seen to be internationalizing. Other places in South Asia have not had comparable levels of private investment in law schools. This may change in the future but it is yet to be seen whether such global law schools will ultimately cater to local needs.

International division of labour and academic dependency remain a reality for the Third World. These have a strong impact on how knowledge is produced and by whom. ${ }^{118}$ The categories of knowledge of the social sciences bequeathed to post-colonial nations continue to interrogate knowledge by using conventional Western disciplines as a measure of truth and a tool to comprehend histories and social realities. ${ }^{119}$ It prevents the Global South from claiming intellectual autonomy as the conceptual apparatus of the social sciences is entirely borrowed from the Global North. ${ }^{120}$ The term "brain drain", denoting knowledge and expertise drained from the South, is often associated with these concepts. This phenomenon does not just occur with the physical relocation of the Third World scholar from the South to the North. International work pushes local scholars to focus on funding potential and the marketability of research agendas based on the needs of and demands from the North. The financial yields of

117 See JS Gandhi, "Law as an Instrument of Change in India” in Indra Deva, ed, Sociology of Law (Oxford: Oxford University Press, 2005) 99.

118 These problems have been perceived to be part of the larger context of relations between the former Western colonial powers and subsumed under various concepts of academic imperialism. For a representative sample, See SH Alatas, "Intellectual Imperialism: Definition, Traits, and Problems" (2000) 28:1 Asian Journal of Social Science 23; Edward Said, Orientalism (New York: Vintage, 1979.); Samir Amin, Eurocentrism $2^{\text {nd }}$ ed, translated by Russell Moore \& James Membrez (NewYork: Monthly Review Pr, 2010); Immanuel Wallerstein, "Eurocentrism and its Avatars: The Dilemmas of Social Science" (1997) 46:1 Sociological Bulletin 21.

119 See Vinay Lal, Empire of Knowledge Culture and Plurality in the Global Economy (Chicago: University of Chicago Press, 2002).

120 As a result, many scholars have called for: alternative discourses in the social sciences (see Farid Alatas, Alternative Discourses in Asian Social Science: Responses to Eurocentrism (Thousand Oaks: Sage, 2006)); the decolonization of knowledge (see Walter Mignolo, "The Geopolitics of Knowledge and the Colonial Difference" (2002) 101:1 South Atlantic Quarterly 57); Nandy Ashis, Intimate Enemy (Oxford: Oxford University Press, 1989)); critical pedagogy (see Paulo Freire, Pedagogy of the Oppressed (London: Bloomsbury Publishing, 2000)); and post-colonizing knowledge (see Gyan Prakash, "Writing Post-Orientalist Histories of the Third World: Perspectives from Indian historiography" (1990) 32:2 Comparative Studies in Society and History 383; Dipesh Chakrabarty, "Postcoloniality and the Artifice of History: Who Speaks for 'Indian' pasts?" (1992) 37 Representations 1). 
international work in the form of legal instruction, research projects and consultancies are much more lucrative for local experts. This reduces them to the role of knowledgeable informants. Local expertise continues to be subordinated over international expertise. As a result, institutions also suffer from brain drain. Moreover those working in the Global South have significantly disparate access to scholarly tools and knowledge repositories. The imbalance of wealth between the North and South translates to accessing scholarly resources in an almost neo-colonial fashion. ${ }^{121}$ For instance, this phenomenon is manifest within South Asian legal history, whereby university libraries in South Asia struggle to secure access to latest monographs published in the United States and United Kingdom. Therefore, scholars located in Euro-America, including those within the South Asian diaspora retain a monopoly and privilege on the production of knowledge. ${ }^{122}$ This kind of disparity also extends to other disciplines. While the internet is a means of facilitating interconnection and access to free resources, it is doing little to address the digital divide between the Global North and South. Many online databases essential for cutting edge research are available by subscription only, which means that, compared to their Southern counterparts, Northern universities with access to such databases enjoy widespread access. ${ }^{123}$

The lack of a critical mass of legal scholars, absence of peer-groups, professional hierarchies, and access to knowledge repositories are commonly-cited problems in many Global South countries. Hossain, given his experience with the Commonwealth, sees some potential in international organizations to be mediums for facilitating the transfer of knowledge and building capacity - though much of this, according to him, is in decline. ${ }^{124}$ Institutions or state-building exercises need expertise and human resources. This deficit can, in some instances as with Bangladesh, be addressed by international organizations or in cooperation with them. However, he also agrees that such success stories depend on institutional leadership, input and activism from a core group of local state and nonstate actors and financial resources. ${ }^{125}$ While transfer is important, effective participation of local agents and channeling knowledge to local institutions are also crucial. Transfers often occur under the guise of missionary projects supporting an entire industry of experts whose expertise is legitimated by their connection to the Global North - it does little for the local institutionalization of knowledge. ${ }^{126}$

Academic dependency coupled with the paucity of research and the practice of expounding black letter doctrine has impoverished legal academia and practice in many places in the Third World. As a result, legal scholarship tends to lack critical and social reflexivity. ${ }^{127}$ The lack of empirical data about the Global South is almost universally acknowledged. Often, ad hoc efforts take place, primarily in the form of qualitative research but these tend to be micro-studies rather than macro or national ones. It may perhaps be more effective to study the Third World through its lived experiences, culture and history as

\footnotetext{
121 See Mitra Sharafi, "South Asian Legal History" (2015) 11 Annual Review of Law and Social Science 309-336, at 320.

122 Ibid.

123 Ibid

124 Interview supra note 47.

125 Ibid.

126 David Kennedy, A World of Struggle: How Power, Law, and Expertise Shape Global Political Economy (Princeton; Oxford: Princeton University Press, 2016).

127 See Gandhi, supra note 117.
} 
its epistemological source. ${ }^{128}$ In places like Bangladesh, knowledge production is now increasingly carried out by other means such as policy research and activism in think tanks, NGOs and other research institutes. ${ }^{129}$ Thus, gradually, a site for unifying theory and praxis may be developing within the Third World that needs to be harnessed through collaborative commitments of both Northern and Southern scholars. $^{130}$

\section{CONCLUSION}

While international law may be traced back to the lives of average Third World citizens - it remains invisible in a material sense. ${ }^{131}$ In most Third World countries like Bangladesh, legal awareness of the average person is generally limited - to a point that in the everyday, most ordinary people avoid encountering the law and all its attendant disciplinary actions. ${ }^{132}$ What is most visible, however, are various forms of oppression and resistance to it. A socially-conscious legal scholactivist is wellpositioned to facilitate such resistance and mediate subaltern claims. This may include, if necessary, relying on hegemonic tools of the state and the international legal order in a counter-hegemonic manner. It implies a double resistance-one is an external resistance to power, while the other is an internal one resisting the pressures of the field, which is conducive to the production of entrepreneurial lawyers rather than those gravitating towards social justice, heteronomy, etc. Delineating the parameters of an acceptable form of politically-active intellectual engagement is a delicate balancing exercise. It also poses other questions about whether these same individuals can speak for marginalized people or communities, without being of the people or from those communities, simply on the basis that those constituencies are prevented or inhibited from speaking for themselves. It is difficult playing a distinctive political role without appearing to sacrifice one's principles and ideals or engaging in what may be perceived to be elitism. Yet, giving a voice to or providing a medium for the marginalized remains a fundamental ethical enterprise for lawyers.

This article set out to trace the process through which lawyers from the Third World use scholactivism in claiming rights for the marginalized. It does not suggest an unequivocal emancipatory role for law or absolute altruistic motives of legal agents, rather it attempted to trace how they navigate the unequal global legal order in furthering their claims. Hossain remains an important protagonist of Bangladeshi legal history and a critical voice on Third World issues. By situating Hossain's activities in Bangladesh, this article attempted to understand the role of lawyers in not just constructing the law but

128 See Mari J Matsuda, "Looking to the Bottom: Critical Legal Studies and Reparations" (1987) 22 Harv CR-CLL Rev 323; Eve Darian Smith also suggests reconstructive approaches for redefining the understanding of law in legal education, see Eve Darian Smith, "The Crisis in Legal Education: Embracing Ethnographic Approaches to Law" (25 November 2015) Transnational Law Institute, Think! Paper, Research Paper Series, online: SSRN <www.ssrn.com>.

131 See Luis Eslava, Local Space, Global Life (Cambridge: Cambridge University Press, 2015).

132 Rajagopal acknowledges this peripherally stating that most people in the Third World interact in non-institutional spaces. See Rajagopal, supra note 11 at 5; Law and Society scholars have also explored this under the rubric of legal consciousness. See Susan S Silbey, The Common Place of Law: Stories from Everyday Life (Chicago: University of Chicago Press, 1998). 
also in connecting places with political spaces. It assessed the impact of geographical location, structural constraints, and knowledge production processes on scholactivistsm. Few legal scholactivists have institutional and intellectual support and often operate within limited or shrinking civil society spaces. They not only confront and navigate structural inequalities, but do so within highly stratified professions.

Despite heavy corporatization and increasing efforts towards deradicalizing dissent, Western universities and institutions remain somewhat semi-autonomous compared to their Southern counterparts. ${ }^{133}$ Scholars who write about the Third World from the North generally tend to do so without fear of political repercussions and threat to security, ${ }^{134}$ while Southern scholars who are physically located and based in the Third World are unable to do so, either because they lack academic platforms and political freedoms, fear persecution, or operate within structural and institutional constraints. Given these realities, scholactivists within the Third World along with their Northern counterparts need to confront the politics of knowledge and the contradictions inherent in their own positionality when claiming a voice for the Third World. ${ }^{135}$ In deploying scholactivism to the subaltern project, the question of "Who will listen?" becomes more important than "Who should speak?" in order to be taken seriously. ${ }^{136}$ So long as the strategies to ameliorate epistemic violence are put in place, location may not necessarily delegitimize the production of knowledge. Uncovering place-based politics may be one approach for developing such ameliorative strategies. ${ }^{137}$

Admittedly, simply linking a place with globalizing forces will not recover subaltern politics. Placebased approaches are not to be equated with being place-bound. Places and social movements can, and often do, harbour internal inequalities and have the potential for co-optation. ${ }^{138}$ Transnational links partially explain the successes or failures of social movements. Domestic laws, institutions and state bureaucracies can and frequently do affect the outcome of counter-hegemonic practices. The state is still widely considered to be an important actor for economic development and enforcement of rights. Thus, there is a need to revisit the idea of sovereignty and the nation state. In light of this, future areas of research on issues affecting the Third World could expand on the notion of place to understand local strategies of resistance and emancipatory practices and how the state as the enforcer of rights features in these movements. It would allow for the mapping of means to implement emancipatory strategies and democratizing regulations. These components are relevant for understanding oppression and the potential for sustainable transformation in the Third World.

133 See Piya Chatterjee \& Sunaina Maira, The Imperial University (Minneapolis: University of Minnesota Press, 2014).

134 There are exceptions to this as well. Scholars may be targeted because of content regardless of location. Authors like Salman Rushdie, Wendy Doniger, etc. have sparked outrage in India but so long as they are in safer spaces in the Northern academies or affiliated institutions, they can continue to pursue their scholarly enterprise. This is difficult for scholars in the South. Bangladesh has experienced fatal targeting of scholars and bloggers in recent years. Some decades earlier, Taslima Nasreen, known for her controversial novels, was forced to seek safer pastures outside Bangladesh.

135 See Sandra Greene, "The Multiple Worlds of African Studies" in Ali Mirsepassi, Amrita Basu, \& Frederick Stirton Weaver, eds, Localizing Knowledge in a Globalizing World: Recasting the Area Studies Debate (Syracuse: Syracuse University Press, 2003) 142; Spivak, "Subaltern", supra note 6.

137 See Prazniak \& Dirlik, supra note 3.

138 See Dirlik, Xie \& Wang, supra note 41 at 44. 
To be emancipatory, laws must be counter-hegemonic and contextual as opposed to elite-favouring. Understanding the Third World through its agents may be a starting point for such reconstruction. Transnational collective efforts may be powerful in facilitating resistance but it is difficult to predict their tenacity in diminishing the forces of exploitation and marginalization. Numerous subaltern counterparts are transnationally connected but geographically scattered. As a result, subaltern struggles require both solidarity and resources. Maintaining a voice in global agendas of policy-making, governance, philanthropy and the academy and through networks of solidarity may be some strategies for scholactivists to contribute to the subaltern project. Collaborative commitments among scholactivists will also require overcoming North-South binaries by focusing on real life experiences of how people deal with the law in their everyday lives, and by considering the intellectual history of the Third-World, and reading and citing the works of Third World scholars. Recognizing the intellectual traditions of the Third World may help ameliorate moral relativism and aid in the construction of concrete normative priorities. ${ }^{139}$ A North-South cross-fertilization already seems to be taking place within academia, making greater room for Third World agency. ${ }^{140}$ This article developed at the invitation of the TWAIL Conference organizers illustrates that such an effort is under way. Moreover, making available several articles produced as a result of collaborative efforts at the TWAIL conference in an open source journal such as the Windsor Yearbook of Access to Justice is also a step forward towards reducing the digital divide between the North and the South.

139 See Matsuda, Ibid.

140 Other disciplines and scholarly groups such as Law and Society have emphasized internationalization and have begun to move meeting locations outside the United States. Groups like the Law and Social Science Network (LASSNet) created by Pratiksha Baxi at Jawaharlal Nehru University in Delhi, India are also working towards connecting global North and South scholars through regional meetings. 